\title{
Local Wisdom: The Development Of Community Culture And Production Processes In Thailand
}

\author{
Utit Sungkharat, Thaksin University, Thailand \\ Piboon Doungchan, Thaksin University, Thailand \\ Chantas Tongchiou, Thaksin University, Thailand \\ Banlue Tinpang-nga, Thaksin University, Thailand
}

\begin{abstract}
The objective of this research was to study the development of production processes and community culture in the Songkhla Lake Basin in southern Thailand. We used a qualitative method and did in-depth interviews with 25 local community leaders in 25 communities surrounding the lake. We found that the concept of community culture was developed through local community leaders to the agricultural production by using culture to run the production process, which is based on the concept of self-sufficiency and self-reliance. From this study, the authors found that this development has led to a decrease in residents' use of technology and a return to the use of labor. The development also reduces the use of chemical fertilizers and insecticides. People have returned to the use of herbs for curing disease in humans and animals. In addition, the development helps people save on production costs and reduce pollution.
\end{abstract}

Keywords: local wisdom, development, production processes, Songkhla Lake Basin

\section{INTRODUCTION}

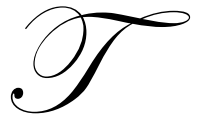

he ideology of country development for modernization has potentially influenced Thai economic development since the first National Socio-Economic Development Plan in 1961. The general concept of this development plan is to develop the industrial sector by utilizing surplus products from the agricultural sector in the industrial sector. In addition, the plan also aims to develop the infrastructure of rural areas, providing knowledge and new technology and supporting education systems to support growth in the industrial sector. These processes become key points in the next National Socio-Economic Development Plan, which has affected change in social, economic, politics, and education perspectives. Consequently, Thai rural areas are facing the most pronounced effects in the change under the ideology of development toward modernization.

The phenomenon has meant that Thai rural areas, especially rural communities and the agricultural sectors, have been drastically changed. The mode of production for consumption in households and communities also has been turned to production for the market and the industrial sector. New technology for production has replaced human and animal labor. New knowledge has been adapted in agricultural work-for example, GMO seeds, chemical fertilizers, and insecticides. Due to production modalities which focus only on the quantity of product in order to supply outside markets, there has been a rise in production costs, given that modern mono production methods cannot support the needs of consumption in households and communities. Communities cannot rely on themselves, since everything is geared to supporting the outside market. Farmers are in debt, and relationships in communities have declined. Moreover, the new education system is not suitable for production in the agricultural sector, but focuses on the industrial sector. This causes the migration of labor from rural areas to the industrial sector. The rural sector is then impacted by the government's ideology of development unavoidably.

Since the reach of state-driven development has progressed to the second of National Economic-Social Development Plan, many sectors have begun to question to what extent development in that direction is appropriate 
to Thai society. The gap in development by sector has continued to increase. At the same time, development has affected villagers by positing them as victims in the discourse of "development," with further effects on the unstable local culture. In addition, the funneling of resources from villagers to capitalists is worse. It is believed that the said development has been created from needs superimposed from outside (by the state). Government officials are unfamiliar with the efficiencies of people or communities. This is also an important cause of the push for villagers to labor in the service of capitalism. Villagers cannot stand by themselves, and communities are weakened and collapse finally.

The suggested alternatives, which fall under the concept of community culture, were proposed in 1977, created by private organizations in Thailand. They follow a conceptual development approach, using a concept from Christianity - that is, if humans who have cultural beliefs follow their cultural beliefs, then they survive (Walter M. Abbot, 1966: 36). This approach strongly supports local community cultures in Thai rural development. Moreover, philosophers and academicians of community culture from major universities in the country have presented papers which support the approach of community culture. These parts are important to develop the concept to create the space of creative in Thai society (Phongphit, 1986; Chitakasem \& Turton, 1988: 118-141). Moreover, there are also developers from private organizations who have increased their participation in rural community development (Tongsawate \& Tip, 1985: 38-40). This results in more academic papers about community and development in the intervening decades. For example, Kemp (1991) published a book titled The Dialectics of Village and State in Modern Thailand, and Suwana-adth (1993) published The NGO Sector in Thailand: The Potential Role of NGO in National Development.

The trend of community culture has spread over Thai society, and has captured the attention of first-class academicians. Moreover, papers about folklore from local academicians in other regions of Thailand also are the keys to elucidating ways of life, social customs and cultures, and local traditions. This pushes the development of community culture to the fore in the mainstream of development.

The concept of community culture development, which states that "community" is created, has been defined as the anti-modernization approach (Kitahara, 1996: 16). The development has to turn back to start at "community" again by trust in the community's efficiency so that its people can restore, live, and develop on their own according to their beliefs, relationships in the community, and their folk wisdom. It is believed that this is the only way that villagers in rural areas can respond to the government plan and find out the right way to solve their problems. This approach changes the frame of viewpoint in development from the old one-that culture is a problem - to a new one which holds that development cannot occur when economic, social, and cultural aspects are isolated from each other. It also defines new meanings of development, along the lines not only of the model of economic development, but also exposing the hidden value in said development.

Consequently, so-called cultural restoration has become a strategy in development. The goals of cultural restoration have two perspectives: 1 . oppose power to outside culture, which has different values and tends to attack old culture; and 2. the cultural restoration for creating a culture of development in each community. These perspectives start from the old culture or combine the old and new culture, and focus on the participation of villager as the persons who create the definitions of "culture" and "development." Villagers also create their own goals and processes, and are the beneficiary of development as well.

The community culture development has been combined into the concept of participation and civil rights. This is one of the ideas inherent in the concept of empowerment for communities in Thailand. The heart of cultural restoration for empowering community is to return to localism by restoring traditional values such as culture, tradition, knowledge, and local consciousness, especially local wisdom. Local wisdom is knowledge that villagers have created and experienced generation after generation: This is experience directly gained from the practical, and indirectly as from transmission by elders of knowledge, values, culture, ways of life, and so on.

As we mention above, villagers in Songkhla Lake Basin in the southern part of Thailand have adapted different forms of development into rural development. One of these is the change in modes of production in the agricultural sector by creating techniques, patterns, and processes of production. Villagers have used local knowledge and local wisdom, and integrated those with the concept of self-reliance and self-sufficiency. They 
believe that this will be the alternative choice for development in a way that secures the wellbeing of their communities. These methods include, for instance, feeding fish in the rice field, integrated farming, Buddhist farming, agro-forestry, etc. Villagers believe that new production models are the farming alternatives which will lead them to sustainable development. Hettne (1990: 152-194) states that this choice of development has been widely known since 1975, especially with regard to a concept which is developed in a journal of Development Dialogue and Alternative. This concept has been used and modified by the neo-populists toward development goals in developed countries.

The practical succession model in the rural sector in Songkhla Lake Basin has many authors have studied achievements in agricultural sector farming where the concept of community culture is in use, and has propagated its findings to the public through media. They admire the models as local wise people who are leaders of production change in community. They accomplish alternative farming by trying to integrate knowledge from outside, and to link it with their local knowledge. They believe that this process helps them learn through the practical, based on the participation of and the relationships between people within community. That concept also focuses on the role of transferring knowledge to other villagers by local wise people.

The achievement of the agricultural model in farming has upgraded local wisdom to be the potential knowledge in development, and put the local wisdom in the academic field to spread local knowledge. At the same time, knowledge from local wise people in Songkhla Lake Basin was transferred to villagers. In addition, we have defined the meaning of local wise people as people who successfully integrate local wisdoms into production modes and became model for villagers. Local wise community leaders are also honored by the official sector, private sector, and academic institutes as people who fight against globalization and promote independent and stable living.

Self-reliance is a key point in the local wise people's production mode in Sonkhla Lake Basin. They asked themselves why people in the past could live self-sufficiently and why people in the present could not. Though people produce a lot, they are still poor. How did the people in the past do it? The answer they found is that people in the past produced for eating and living, not for selling. Thus in the past villagers did not need to do a lot of farming. They planned everything to eat in the house. They did not have to buy in the market. They fed the animals for food and work. This was a way to decrease expenses. They first kept the products to eat, and then they sold the product excess. So, the objective of this study is to study the development of production processes and community cultures in Songkhla Lake Basin in southern Thailand.

\section{METHODOLOGY}

The areas covered by the study are villages and communities of the Songkhla Lake Basin in the southern part of Thailand. This area is a bio-diverse area which consists of swamp forest, coast, island, and low plain. Due to the geological conditions in this region, the production mode of the people in the community around it is diversified and has different efficiencies in each local area. Villagers use production techniques which match their environments and the social and cultural contexts in their areas.

The authors conducted the study by using an in-depth interview of 25 local wise people in 25 communities surrounding Songkhla Lake Basin. The interviews lasted 1 to 2 hours and were designed as a semi-structured interview. The authors developed the questions in the interview to conform to the objectives of the research by using theoretical perspectives based on the qualitative approach of the study and a critical sensibility to find out the degree and complexity of social operations (Denzin, \& Yvonna, 2000: 7). For the selection of key informants, the authors used Strauss and Corbin's theoretical sampling (Strauss \& Juliet, 1990: 42-43, 177-179). The authors then chose the characteristic of the first group of key informants, who must be local wise people, admired by officials or private organizations. These local wise people must be experts in production, management, integration of knowledge between traditional and modern knowledge, and so on.

Regarding the collection of data, the authors analyzed the data to develop concepts and categorize data at the same time. The authors also selected other key informants who are villagers in the communities when he found data which was different from the categories already created. The data was used to confirm the propositions, and the output released as the theoretical conclusion or temporary hypothesis. In addition, the temporary hypothesis was 
applied as the standard in the subsequent selection of key informants, and the authors chose persons who had different data to contribute for the interviews. The authors then analyzed data by using the theoretical sensibility to analyze and collect the pattern of the negative responses to ensure that although the authors interviewed more at length with key informants, the conclusions would not change.

The authors collected data from the in-depth interviews by using the interview guide, which was developed from the conceptual framework of the research. Recording in the interviews, taking notes, and participatory observation have been used in the study to analyze the situation. After data collection, the authors transcribed the tapes from the interview carefully and analyzed these for developing the theoretical conclusion. Afterward, the authors created the concepts by interpretation and defined the meanings of concepts in many dimensions. Then, the authors categorized data to set up the propositions and theoretical generalization to describe the local wise people's knowledge and the concept of development by using community culture as a main idea. Finally, the case is presented by descriptive analysis.

\section{RESULTS OF THE STUDY}

This study of the production modes and the local wise people's community culture in the Songkhla Lake Basin region discovered that self-reliance contributes to villagers self sufficiency. These are the principles of production per the findings: 1) Villagers work and create for themselves; 2) Planting home-grown vegetables by planting alternately fruit and perennials, they have to plant two to three stems every day in the rainy season; 3 ) Raising animals that can sustain themselves or eat food scraps; 4) "Plant less, get more; plant more, get less" means that even when they plant less, plants produce more because farmers prepare the plantation with more care; 5) Do not use chemical fertilizers or insecticides; instead, focus on the development of soil and environment in the farm; 6) Producing rice by themselves to eat and feed their animals; and 7) Planting herbs for curing, and using more traditional treatments than modern treatments.

These processes constitute the production modes of the self-reliance approach. They apply local wisdom in natural production to save costs. This production is based on the community's culture, which conforms to the geological conditions and promotes economic stability in the community. In addition, the study also found another kind of applied local wisdom which is used in the agricultural production, that is, "to plant relying on experience." Villagers found this principle through experience; the idea departs from the observation that many plants live together in the forest. Thus, there are several products because each plant produces at different times. Given this idea, it is not necessary to do mono-crop farming, or to plant in an ordered fashion. Farmers can put different plants in the same soil by selecting plants which support each other. This is a local Thai wisdom from rural parts of Thailand.

In addition, community cultural development is related to local wisdom that is transferred from generation to generation by local wise community leaders. The authors found the following four significant factors that are related to the production process, cultural community, and local wisdom.

First, local wisdom and production process. The production process in a rural community is the same as what was used many years ago and is developed by using local wisdom that relates to nature and protection. The communities surrounding the Songkhla Lake Basin are agricultural, so they are related to nature and the environment. Therefore, the residents' production process is based on managing the human and natural systems. In addition, local wisdom helps them to manage their production to grow agricultural products. After the people have taken what they need to sustain themselves, the excess production will be sold. Because the only labor expended is that of family members, the cost of production is low. This shows that by using local wisdom, a cultural community helps rural people survive during this period of globalization.

Second, local wisdom and health. In order to preserve the residents' health, local wisdom is transferred from a forefather concerning herbs that can be used medicinally. For example, Sesbania grandiflora (Sesban) is boiled, and people drink the resulting tea when they get a stomachache or a headache. Tiger herbal boil is drunk to reduce blood pressure. Garlic is eaten to lower cholesterol. Margosa leaves are used in a drink to treat malaria. 
Third, local wisdom and the environment. As mentioned above, the authors found that local wisdom is used to protect forest land and the natural environment that are the center of life in these communities and necessary for people's survival. Because they believe that humans cannot survive if they do not preserve the natural environment, some people plant trees around their land, without having to pay for concrete and brick to build a wall. They receive many benefits from the trees which protect their land. In addition, this can improve the environment and reduce pollution in the area.

Fourth, chemical fertilizers and farming. Chemical fertilizers are not used on farms in the Songkhla Lake Basin where agriculturists use natural fertilizers such as dung from animals because of knowledge passed from generation to generation. Because they use natural fertilizers, farmers will not need to invest money to buy chemical fertilizers, 2) their families will be healthier, and 3) their agricultural produce will appeal to consumers who want untainted food products.

Consequently, the use and application of local wisdom based on self-reliance and self-sufficiency has increased the local wise people in the community has work an outstanding. Local wise people in any kind of knowledge then have their own identity based on morals, responsibility, and sacrifice.

With the process that wise people use in production, local wisdom is potentially adaptable and can result in new methods of production. Many sectors in production have created their own identities by learning from the failures of ineffective government policies. Everyone has failed before in terms of debt accumulation and overdemand for a certain products. This is enough reason to convince them to reconsider their ideas and to change the production mode to conform to local wisdom. In addition, local wise people use local wisdom in management principles guided by morals, ethics, and truthfulness values. These elements bring confidence to the community, which is able to extend these modes to managing many other projects. Local wise people then become people admired by the villagers and the community. Accordingly, they become people who think, do, and live by their own collective counsel, and who thus have sustainable lives.

\section{DISCUSSION AND CONCLUSION}

The concept of community culture has been developed by using culture as a core, and adapts local wisdom to use in the agricultural production process through the local wise people who offer a model of production in communities. Local wise people have adapted local knowledge into production modes by using concepts of selfreliance and self-sufficiency. This knowledge includes, for instance, the products of person and animal labor in the household, planting vegetables to feed a family in home gardens, using bio fertilizers, feeding fish in the rice field, agro-forestry, integrated agriculture, organic agriculture, the management of resources by people in a community to save the environment, settling the learning network between communities, etc.

All of these are examples of using community culture to manage by applying local wisdom and cultivating inter-reliance in the relationships between villagers in communities. This process requires that local wise people lead and provide the guiding concepts to villagers in communities. The process helps villagers live self-sufficiently, and focus more on producing enough to live rather than to sell in the market. Villagers can thus decrease debts, and do not have to lean on the market or capitalist practices. These effects then cause the community be strong. This has been defined as a new path for development by using community culture to run the process. Development facilitated through the concept of community culture then is the alternative choice for development which leads to sustainable development.

\section{ACKNOWLEDGEMENT}

We acknowledge with appreciation Dr. Thongphon Promsaka Na Sakolnakorn for the helpful suggestions and comments on this research article. 


\section{AUTHOR INFORMATION}

Utit Sungkharat is a lecturer at the Faculty of Liberal Arts, Prince of Songkla University, Hat Yai campus, Thailand. He is studying toward his doctoral degree in Cultural Studies at Thaksin University, Thailand. He specializes in and has several publications in cultural studies and in selected topics in anthropology. His e-mail: utit.s@psu.ac.th

Mr. Piboon Doungchan is an Associate Professor and Dean of the Faculty of Humanities and Social Sciences, Thaksin University, Thailand. He received his M.A. from Mahidol University, Thailand, and is specialist in cultural studies.

Dr. Chantas Tongchiou is a lecturer at the Faculty of Humanities and Social Sciences, Thaksin University, Thailand. He received his Ph.D. from Chulalongkorn University, Thailand, and has published several books on issues in linguistics and cultural studies in Thailand.

Dr. Banlue Tinpang-nga is an Assistant Professor at the Faculty of Humanities and Social Sciences, Thaksin University, Thailand. He received his Ph.D. from the University of Iowa in the United States of America. He specializes in Western culture and Western linguistics.

\section{REFERENCES}

1. Chitakasem, M. \& Turton, A. ed. 1988. The Construction of Knowledge. London: University of London.

2. Denzin K. Norman \& Yvonna S. Lincoln. (eds) 2000. Handbook of Qualitative Research. London: Sage Publications.

3. Hettne, B. 1990. Development Theory and the Three Worlds. New York: Longman Scientific \& Technical.

4. Kemp, J. 1991. The Dialectics of Village and State in Modern Thailand. Journal of Southeast Asian Studies. 22, 312-326.

5. Kitahara, A. 1996. The Thai Rural Community Reconsidered. Bangkok: The Political Economy Center, Faculty of Economies, Chulalongkorn University.

6. $\quad$ Phongphit, S. 1986. Back to the Roots: Village and Self Reliance in Thai Context. Bangkok: Village Institution Promotion.

7. Strauss, A. \& Juliet, C. 1990. Basics of Qualitative Research: Grounded Theory Procedure and Techniques. London: Sage Publications.

8. Suwana-adth, M. 1993. The NGO Sector in Thailand: The Potential Role of NGO in National Development. Bangkok: SVITA Foundation. (Unpublished Paper).

9. Tongsawate, M. \& Tips, W.E.J. 1985. Coordination Between Governmental and Non-Government: A Case Study of Planning and Implementation of Integrated Rural Development at the Local Level. Bangkok: Division of Human Settlement, Asian Institute of Technology.

10. Walter M. Abbott, S.J. 1996. Dogmatic Constitution on the Church. New York: America Press. 